\title{
Curriculum Delivery Constraints of Arabic Language as a Foreign Language in the UAE
}

\author{
Mohamad Ezzat Alkutich \\ British University, Dubai
}

\begin{abstract}
This paper illustrates the constraints of the curriculum delivery of Arabic as a Foreign Language (AFL) in the United Arab Emirates Senior School. As the UAE is one of the Arab countries, so the Arabic language is a key subject of the national curriculum which compulsory for students in all year groups for both types of students, local citizens and residents. The aim of this study is to investigate the constraints that face the teaching and learning of AFL, such as, teaching AFL speaking, understanding pupils' differentiation, learning resources, classroom activities, teaching methods, and speaking assessment. A qualitative research methodology is employed; a semi-structure interview was the main tool with a sample of 2 heads of departments, four AFL teachers and 6 students. The main research question is "what are the constraints of curriculum delivery of AFL in the UAE?" This study provides solutions to the discussed constants in order to improve the quality of curriculum delivery of AFL as well as its quality of teaching and learning.
\end{abstract}

Keywords: component; formatting; style; styling; insert (Minimum 5 to 8 key words)

\section{INTRODUCTION}

The UAE is one of the Arab countries, and the Arabic language is one of the key subjects of the national curriculum besides Islamic Education and Social Studies, That are compulsory for students in all year groups for both types of students, local citizens and residents. Teaching Arabic language for non-Arabic speakers has become increasingly significant in UAE. Arabic language is a compulsory subject in all levels of UAE's schools. The focus of this study is the curriculum of Arabic language in Emirati private and international secondary schools. The general standard objectives of Arabic language for non-Arabic speakers at secondary schools in UAE are the same as English as a second language: (1) improving oral and written communication skills in order to obtain informational literacy level; (2) increase the awareness of the importance of Arabic language worldwide; (3) developing the awareness of learners about the relationship between the Arabic language and Arabic and Islamic culture (Depdiknas RI, 2006).

\section{PROBLEM STATEMENT}

Even though Arabic as AFL is a compulsory subject and is taught for all year groups, but still very few numbers of AFL pupils who can communicate in simple Arabic. The reasons beyond this issue vary. Some of these reasons are behind of school context so educators have no control over them. Such as, the domination of English language worldwide as it is the language of new sciences and a default language of technology, another reason is that the Arabic language has many different dialects not as other foreign languages. On other side, other reasons are under the control of educators as they are the focus of this study.

\section{THE RATIONALE OF THE STUDY}

Based on my experience as I was an Arabic teacher for English speakers and as a subject coordinator in one of the UAE international schools, I was facing this dilemma of the quality of teaching and learning of Arabic language. No one of school players is happy with the performance of the Arabic language, each one of these players throw the ball at others, eventually and unfortunately, the weakest among these players is the teacher. School inspectors, head teachers, heads of departments, pupils and parents blame teachers for this failure. As a teacher I see that this is unfair judgment and all school players are responsible for this failure, but as a researcher I am trying here to search for all the constraints that face Arabic language and then try to offer solutions in this regard. There is not that much of research conducted to discover the reasons behind these shortcomings in learning Arabic as AFL. The only available publications about this issue are the school inspection reports provided by KHDA in Dubai and ADEC in Abu Dhabi. However, these reports and their finding are criticized by school players as these two school inspection instruments are in their 7 years age and the result of AFL performance still the same not as expected (Alkutich, 2016 ). This research tries to add to the literature a reliable academic reference, as well as to provide educators and education stack holders some answers about the constraints that face the process of curriculum delivery of AFL

\section{THE PURPOSE OF THE STUDY}

The aim of this piece of research is to investigate the constraints that face curriculum delivery of AFL in the UAE international schools, as well as to suggest some answers that might help them to solve these constraints.

\section{THE SIGNIFICANCE OF THE STUDY}

The significant of this research comes from that there is not that much of academic research conducted about the reasons behind the shortcomings in teaching and learning Arabic as AFL. The only available publications about this issue are the school inspection reports provided by KHDA in Dubai and ADEC in Abu Dhabi. This research tries to add to the literature a reliable academic reference, as well as to provide educators and education stack holders some answers about the constraints that face the process of curriculum delivery of AFL

\section{RESEARCH QUESTIONS}

This study was built on one main research question in addition to other five sub-research questions. The research question is 
"what are the constraints of curriculum delivery of AFL in the UAE?", and the five sub-research questions are;

1- What are the school based-curriculum constraints that face AFL?

2- What are learners' differentiation constraints that face AFL?

3- What are the constraints of learning material resources that face AFL?

4- What are the classroom activities constraints that face AFL?

5- What are the constraints of teaching and learning methods that face AFL?

\section{LITERATURE REVIEW}

Arabic language as a foreign language AFL is called as Arabic B in majority of UAE schools, as well as Arabic for non-Arabs. In this study I will use the first terminology which is Arabic language as a foreign language or AFL. As it is mentioned earlier, there are few studies in the literature that focus on AFL.

Arabic language the mother language of 22 Arab countries, and it is the language of the Qur'an the holy book for Muslims all around the globe that have to memorize some chapters from the Qur'an to be able to perform their prayer (Wahba, K., 2014; Alhawary, M. T., 2013). Arabic language is one of the worldwide spread languages, it is spoken by about 250 million people, and it is one of the six official languages in the United Nations (UN.org, 2017).

\section{LEARNING ARABIC AS A SECOND LANGUAGE}

Arabic language as a foreign language AFL is called as Arabic B in majority of UAE schools, as well as Arabic for non-Arabs. In this study I will use the first terminology which is Arabic language as a foreign language or AFL. As it is mentioned earlier, there are few studies in the literature that focus on AFL.

Arabic language the mother language of 22 Arab countries, and it is the language of the Qur'an the holy book for Muslims all around the globe that have to memorize some chapters from the Qur'an to be able to perform their prayer (Wahba, K., 2014; Alhawary, M. T., 2013). Arabic language is one of the worldwide spread languages, it is spoken by about 250 million people, and it is one of the six official languages in the United Nations (UN.org, 2017).

\section{CONSTAINTS OF AFL BASED ON SCHOOL CURRICULUM}

Private schools in the UAE are school based-curriculum, these curriculum are different. Such as, Arabic, Islamic, American, British, Indian, Pakistani, and others. All these schools are required to teach Arabic. In this study the focus is only on the English curriculum schools, such as American and British. The features of school-based curriculum are two competences, competence standards (Speaking, writing, reading and listening) and the basic standards which mean the distribution of these four language skills on different year groups, such as three years in secondary school. In order to students to achieve these competences, the educators designed for each grade some goals and learning objectives.

\section{CONSTRAINTS OF AFL ON CLASSROOM ACTIVITIES}

Alasraj (2014) as a result of his study is increasing the awareness of AFL teachers about the role of internet and technology in classroom activities.

\section{CONSTRAINTS OF AFL ON TEACHING AND LEARNING METHODS}

Different studies conducted about Arabic as a foreign language, some of these studies focused on teaching and learning strategies that improve the quality of the subject (El Essawi, R., 2013). A study conducted in Saudi Arabia, Alasraj (2014) compared between the effectiveness of the traditional and blended learning strategies in learning AFL at the Islamic University in Medina. The results of his study showed that the blended learning strategies have greater impact in imparting knowledge, besides, blended learning strategy developed students independency and enhanced them to experience different way of content learning. Another study conducted by Aburezeq and Ishtaiwa (2013) in the UAE, the researchers in their qualitative study investigated the perceptions of pre-service Arabic teachers about the influence of Whatsapp mobile messaging as a tool of improving students' instructional engagement. The study found that using WhatsApp in teaching and learning AFL enhance the power of the three types of interaction, pupil-pupil interaction, pupil-content interaction, and pupil-teacher interaction.

\section{RESEARCH METHODOLOGY}

This study investigates the constraints that face the quality of teaching and learning of AFL in UAE secondary schools. A qualitative methodology is employed in order to collect the viewpoints of the participants. This qualitative research strategy permits the researcher to get a close look to the viewpoints of participants about the obstacles that affect curriculum delivery of AFL (Yin, 2011:P.8). Creswell highlighted that qualitative methodology allows the researcher to get better understanding of the phenomenon (2012).

\section{RESEARCH SAMPLE}

This study is a case study with two private secondary schools in UAE, these two schools located in Abu Dhabi, and both of them international schools that teach Arabic as AFL. The curricula of these two schools are British and American and the spoken language is English.

In order to build strong questions that are relevant to the research question, A pilot study was conducted with one teacher and 3 students. This pilot study helps the research to estimate the time needed to the interview. 


\section{RESEARCH PARTICIPANTS}

This study, employed 12 participants from the both sampled schools. The participant were distributed equally in both schools, from each school there was one head of department, two Arabic language teachers and 3 students. An email was sent to 8 schools as invitation to participate in this study; however a positive response received from only 3 schools. The teachers were one teacher AFL of GCSE curriculum, and one AFL teacher for IB curriculum. Whereas, students participants were 3 follow GCSE and 3 for IB.

\section{DATA COLLECTION}

In order to launch this study an email was sent to the principals of these participants schools to get the permission to conduct this study. When permission was received, another email was sent to the participant head of departments and teachers, with this email also the researcher sent consent for ethical clearance to be signed by the participants. However, three students of each school were chosen randomly with the help of heads of departments who ask the students that we need three students of Arabic class to volunteer to participate in this study.

\section{SEMI-STRUCTURED INTERVIEW}

In this qualitative research a semi-Structured interview was employed as the main tool to collect the data and findings of this study. The importance of semi-Structured interview as it is supportive to extract data from participants' opinions, and the shortcomings of semi-Structured interview are the unwillingness to reveal their experiences and the potential bias.

\section{DATA ANALYSIS}

Right after data collection, the second stage of the research is data analysis. Data analysis refers to the process of interpretation of the collected data. The purpose of data analysis is to make sense from the viewpoints of the study partakers (Jansen \& Vithal, 2001). Part of data analysis, the researcher employed content analysis method which is important to offer a briefing of the collected data. Moreover, content analysis enables the researcher to code, categorise and compare data, as well as it shapes the research theoretical conclusion (Cohen et. al., 2011).

\section{RESEARCH CREDIBILITY}

The credibility of this study is ensured by applying different tools; such as, the triangulation tool by using different categories of the participants (Creswell, 2012), namely, head of department, teachers and students. Besides, the researcher retrieved relevant documents to the research questions. Moreover, a pilot study was applied with one teacher and three students.

\section{RESEARCH DEPENDABILITY}

The researcher ensured a high level of dependability in this qualitative study by different ways. So, the notes, records and transcripts were preserved. Moreover, the researcher made sure that participants were treated as partners. Finally, the research ensured that interview questions relevant to research questions, so there will be no or less effect on the findings because of the experiences and potential bias of the participants, I made certain that the are relevant to the research questions, and I also did not use any leading questions with the interviewees.

\section{ETHICAL CONSIDERATIONS}

The issue of ethical consideration is one of the important features of qualitative research. Trust and privacy protection are ensured in order to guarantee that interviewees reveal their perceptions based on their own experiences (Creswell, 2012). For this reason, the researcher sent via email, a consent form about ethical clearance to be signed by the contributors. Moreover, the research ensured that all the participations are volunteers, and they were informed that at any time they can withdraw, also, permission for audio recording was requested.

\section{THE FINDINGS DISCUSSION OF THE STUDY}

The distribution of the research participants were equally divided on both schools for each participant's category. These two schools were international schools, located in Abu Dhabi, the spoken language in both of them is English language, one is American and the other is British. Majority of teachers and heads of departments have teaching experience more than 10 years, with $50 \%$ have minimum education of bachelor degree in Arabic and 50\% of them with post-graduation diploma in Arabic language. Moreover, teachers and heads of departments participants were 4 females and 2 males, all of them were below 45 years old.

On other side, students were 4 females and 2 males, they were equally distributed as one third for three years groups year 10, year 11, and year 12 . Moreover, students' participants were not attending AFL in all their previous academic years, this shows the importance of teaching differentiation as not all students in AFL class have the same Arabic knowledge. So, here in this study, about $65 \%$ have more than 5 years learning Arabic, and about $35 \%$ have 3 years or less of learning Arabic. 


\begin{tabular}{|c|c|c|c|c|c|c|}
\hline Participant & School & $\begin{array}{c}\text { Teaching } \\
\text { experience } \\
\text { per year }\end{array}$ & $\begin{array}{l}\text { Student's } \\
\text { Grade }\end{array}$ & Gender & Age & Qualification \\
\hline $\begin{array}{l}\text { Head of } \\
\text { department } 1\end{array}$ & A & 19 & 7 & M & 44 & Bachelor degree in Arabic \\
\hline $\begin{array}{ll}\text { Head } & \text { of } \\
\text { department } 2 & \end{array}$ & $\mathrm{~B}$ & 10 & 1 & $\mathrm{~F}$ & 33 & $\begin{array}{l}\text { Post-Graduation Diploma \& Bachelor } \\
\text { degree in Arabic }\end{array}$ \\
\hline Arabic teacher 1 & A & 12 & 2 & $\mathrm{~F}$ & 35 & $\begin{array}{l}\text { Bachelor degree in Arabic and } \\
\text { Islamic }\end{array}$ \\
\hline Arabic teacher 2 & A & 15 & 0 & $\mathrm{~F}$ & 37 & $\begin{array}{l}\text { Post-Graduation Diploma \& Bachelor } \\
\text { degree in Arabic }\end{array}$ \\
\hline Arabic teacher 3 & B & 16 & 4 & M & 40 & Master degree in Arabic \\
\hline Arabic teacher 4 & $\mathrm{~B}$ & 4 & 0 & $\mathrm{~F}$ & 28 & Bachelor degree in Arabic \\
\hline Student 1 & A & - & 11 & $\mathrm{~F}$ & 16 & 5 years learning AFL \\
\hline Student 2 & A & - & 11 & $\mathrm{~F}$ & 16 & 9 years learning AFL \\
\hline Student 3 & A & - & 12 & M & 17 & 9 years learning AFL \\
\hline Student 4 & B & - & 10 & M & 15 & 7 years learning AFL \\
\hline Student 5 & $\mathrm{~B}$ & - & 10 & $\mathrm{~F}$ & 15 & 2 years learning AFL \\
\hline Student 6 & $\mathrm{~B}$ & - & 12 & $\mathrm{~F}$ & 17 & 3 years learning AFL \\
\hline
\end{tabular}

Table 1: Research Participants Demography distribution

(School A or B it does not mean that A for American school nor B for British school, it is just coding).

\section{THE PILOT STUDY}

The importance of a Pilot study in qualitative research, comes from the intention of the researcher to guarantee that the interview questions with teachers and students are relevant to the research questions, and to ensure the clarity of questions and the time required for each interview, Kim, (2011) addressed that pilot study is a preparation process whereby the researcher amend the study plan. In this pilot study, one teacher with 3 students were employed from a school that is not involved in the sampled schools. After getting the permission from the principal of this school responding to the researcher email invitation, the research contacted the teacher with three students of his AFL class who were in grade 10; this school follows the American curriculum and students doing AFL for GCSE examinations. 


\section{Research Question 1: School-Based Curriculum}

The first sub-research question was "What are the school based-curriculum constraints that face AFL?", and the responses of the participants came as the following;

Heads of departments showed that the context of international schools is not that healthy for teaching Arabic language whether for native or non-native speakers, as everyone speaks English, and Arabic language is not in the top interesting second language for most of them. One head of department said: "Besides all other core subjects that our students study, you find that most of them lack motivation to learn Arabic, as they feel that they are forced to do it, since it is a part of the national curriculum and it is not part of their choices". Another head of department added: "Teaching speaking Arabic is a complex task, as Arabic language has many dialects, and teachers sometime are not committed to teach the official Arabic regardless teachers dialect background ".

On other side, teacher feels that international schools bias to the curriculum of the school and are not serious when it comes to subjects like Arabic language. One teacher had this to say: "In Arabic speaking class, not all pupils have the confidence to speak", another teacher pointed: "I face multiple challenges in my class, some students are forced to attend and their behaviour is not as expected, some students have no background in learning Arabic, as they just have one year in the country and never studied Arabic before".

Similarly, students of AFL believe that it is difficult to learn Arabic and they do not give the required time to learn and practise Arabic language, besides, teachers do not give equal balance for teaching each language skill. One student said: "I feel anxious in Arabic class and prefer to keep silent", another student added: "I have too many subjects to study and to do homework and I prefer to learn Spanish as my second language", on other side, one student addressed: "Our teacher teaches us for the exam not to learn or to speak the language, he uses English language to explain the topics".

\section{Research Question 2: Learners Differentiation}

Responses of participants on the second sub-research question "What are learners' differentiation constraints that face AFL?" fallen into two themes, students attitudes and students motivation.

\section{Students' Attitude}

Attitude is to have a mental position toward the subject such as behaving and thinking. Positive or negative view of students toward Arabic language has great impact to establish their attitude. Students who have a positive belief about Arabic language have a high possibility to obtain their attraction toward learning Arabic. One head teacher said: "we are challenged in Arabic that majority of our students do not show positive attitude in Arabic class, also some of the teachers believe that we can't change students' attitude or inspire them".

Similarly, one teacher said: "Some of my students believe that learning Arabic is not important for them", another teacher added: "I use to explain how important is the Arabic language and I use different strategies and techniques with lots of educational games to get their attention and attitude, it works while they are in the class but many of them dedicate not time to the subject at home"

However, a student participant said: "I am trying my best to pass the Arabic exam as I have to, but with the minimum efforts" another one added: "I can't concentrate because the behaviour of my classmates is really bad, they do not behave the same way in other subjects like maths and science".

\section{Students' Motivation}

Motivation of AFL (Arabic as a Foreign Language) learners is one of the challenging issues in UAE's international schools. Motivation can be maximized by activities that students use to achieve their goals, when students attitude toward Arabic is positive, they will have higher expectation (Blanchard \& Thacker, 2007). However, in the context of Arabic as AFL in this study, the responses of the participants were in different direction. A head of department said: "Pupils come to the Arabic class just to fulfil the attendance list", another head of department added: "Most of students in AFL are passive learners". The same head of department said: "Some Arabic teachers are not motivated in their teaching, they do their job without enthusiasm".

Regarding teachers participants responses, one teacher articulated: " one of the reasons that my students are not motivated is that they feel hesitate of doing mistakes if they try to speak Arabic", one other teacher added: "I am quite sure that no one of them practise Arabic outside the class". Similarly, students presented their lack of motivation but for different reasons. One student said: "I learn Arabic just to get good marks", Another student added: "Why do I have to learn Arabic?!, I will never use it, and it is very difficult".

In order to solve these challenges, one head of department said: "I think that we need to use students centred teaching strategies so students will be active and engaged in the class activities", one teacher added: "Our school has to build a new policy for motivation, by certificates, commendations, points, or anything good to attract them ", one students suggested: "I think if the teacher teaches us by digital games and work then we can learn better".

\section{Research Question 3: Subject Materials and Resources}

Resources and materials are significant for learning Arabic language, so special materials and resources for communicative activities. Besides, the use of technology plays a significant role as part of the teaching and learning process (Al Musawi, A.,et. al, 2016). However, most of the research participants agreed that textbooks still the main focus in Arabic language classroom. The responses of the third subresearch question "What are the constraints of learning material resources that face AFL?" can be summarized as the following: One head of department said: "The textbook is very important, and we should follow it as it is required from the ministry", one teacher had this to say: "I can't neglect the textbook, as some parents use to ask about the work on the textbook, also school inspectors will check students work based on the textbook that the is required by the educational authorities". One students added to this point: "we feel bored because just we follow the textbook, and there are too much details so we can't finish them all, I think the curriculum is too much" 


\section{Research Question 4: Classroom Activities}

Classroom activities means here the domination ratio of teach versus students. The responses of the third sub-research question "What are the classroom activities constraints that face AFL?" can be summarized as the following: One head of department said: "Some of the teachers lack questioning techniques, I observed one teacher once, she asked a student one question, and while the students trying to think and then give the answer, the reset of the class was doing nothing and some were chatting because they have no task to do", one teacher, on other side, said: "When I give a task to the class to do with their peers, some of them do not follow the instruction and do nothing". One student shared: "We just sit and write or listen to the teacher while he explain and talk the whole time".

\section{Research Question 5: Teaching and Learning Strategies}

Teaching and learning strategies are the activities that used by teachers and learners to facilitate the comprehension of the taught subject. Students can use different strategies and methods while learning the language. The responses of the third sub-research question "What are the constraints of teaching and learning methods that face AFL?" can be summarized as the following: All participants agreed that teachers should use new strategies based on student centred education. One head of department commented: "I always encourage teachers to do group work and peer learning classwork, but some of them prefer traditional methods and use teacher-centred teaching".

One teacher said: "I divide the class in groups, and give them work to do, it works with some students, but for those who lack motivation, they just rely on other group members to do their work" another teacher added: "If we use technology the class will be better, but it is so complicated in the school to book tablets to use computer games". Whereas, one student said: "I do not think that our teacher has plan of what or how to teach the topic", another student commented: "We just sit and write or listen to the teacher while he explain and talk the whole time".

\section{CONCLUSION}

Based on the above findings and discussion, it is found that AFL curriculum delivery in international schools with spoken foreign language face many challenges and constraints. These challenges affect the performance and the quality of AFL teaching and learning. This study distributes the constraints in different categories:

- Educational authorities are not evaluating the implementation of the curriculum.

- Lack of subject materials to enrich the curriculum, there is a misconception between the textbook and curriculum, which limits teacher's freedom and creativity.

- Different assessment for AFL (Ministerial, GCSE, A level and IB) makes teaching Arabic harder, so the teachers will teach for the exam not for learning.
Lack of variety of teaching and learning strategies and techniques. So students feel bored and not motivated.

\section{RECOMMENDATION}

This study suggests some recommendations for reducing the constraints in Arabic as a foreign language, to improve AFL curriculum delivery and the quality of teaching and learning:

- Schools to design smart awarding policies and tools to enhance students' motivation to learning.

- Teachers to attend CPD about teaching and learning strategies and other skills. Such as, learners differentiation, time management, class management, behavioural management, and questioning techniques.

- Teachers to implement student-centred educational approach.

- Head of departments and teachers to design subject curriculum with respect to the textbooks and the national agenda of Arabic language and the interested international exam, by giving teachers more freedom in this regard.

Schools and teachers to support the use of technology, computer games and mobile applications in teaching Arabic.

\section{LIMITATIONS AND FURTHER STUDIES}

This research uses a qualitative methodology by employing two international schools in UAE, so the findings can't be generated to other types of schools or other emirates and countries. I recommend that for future studies to increase the size of sample and use mixed research methodology to investigate the impact of digital-based curriculum, computer games and mobile applications in teaching Arabic.

\section{REFERENCES}

Aburezeq, I.M. and Ishtaiwa, F.F., 2013. The impact of WhatsApp on interaction in an Arabic language teaching course. International Journal of Arts \& Sciences, 6(3), p.165.

Alasraj, A. and Alharbi, H., 2014. The effectiveness of blended learning in teaching Arabic as a second language. International journal of research in humanities and social studies, 1(1), pp.13-17.

Alhawary, M.T., 2013. Arabic second language acquisition research and second language teaching: what the teacher, textbook writer, and tester need to know. al-'Arabiyya, pp.2335 .

Alkutich, M., 2016. Examining The Impact of School Inspection On Teaching and Learning. Dubai Private Schools as a Case Study.

Al Musawi, A., Al Hashmi, A., Kazem, A.M., Al Busaidi, F. and Al Khaifi, S., 2016. Perceptions of Arabic language teachers toward their use of technology at the Omani basic 
education schools. Education and Information

Technologies, 2l(1), p.5.

Blanchard, P.N. \& J.W. Thacker. (2007). Effective Training: Systems, Strategies, and Practices. New Jersey: Pearson Education International.

Cohen, L., Manion, L. and Morrison, K., 2011. Surveys, longitudinal, cross-sectional and trend studies. Research Methods in Education, 7th edition. Abingdon: Routledge, pp.261-4.

Creswell, J.W., 2012. Collecting qualitative data. Educational Research: Planning, Conducting, and Evaluating Quantitative and Qualitative Research. Fourth ed. Boston: Pearson, pp.204-35.

Dajani, B.A.S., 2015. Teaching Arabic Language: Towards a New Beginning that Stimulates Creativity. Procedia-Social and Behavioral Sciences, 192, pp.758-763.

Depdiknas RI [Departemen Pendidikan Nasional Republik Indonesia]. (2006). Pedoman Kurikulum Tingkat Satuan Pendidikan untuk Sekolah Menengah Atas Tahun 2006. Jakarta: Depdiknas RI.

El Essawi, R., 2013. Language Learning Strategies in Arabic as a Foreign Language Textbook. al-'Arabiyya, pp.37-59.

Jansen, J. and Vithal, R., 2001. Designing your first research proposal: A manual for researchers in education and the social sciences. Lansdowne: Juta \& Co, Ltd.

Kim, Y., 2011. The pilot study in qualitative inquiry: Identifying issues and learning lessons for culturally competent research. Qualitative Social Work, 10(2), pp.190206.

Un.org. (2017). Official Languages. [online] Available at: http://www.un.org/en/sections/about-un/official-languages/ [Accessed 3 Jul. 2017].

Wahba, K., 2014. Handbook for Arabic language teaching professionals in the 21st century. Routledge.

Yin, R.K., 2011. Applications of case study research. Sage. 